\title{
INTERNATIONAL ASSOCIATION FOR EARTHQUAKE ENGINEERING
}

At the recent World Conference on Earthquake Engineering held in Tokyo/Kyoto last August, meetings of the IAEE Executive Committee and the General Assembly of National Delegates were held. The following reports were presented at those meetings and summarise the activities of the International Association.

\section{REPORT OF THE IAEE PRESIDENT IN 9WCEE}

The following report will summarize the activities of the IAEE since the Eighth World Conference on Earthquake Engineering in July 1984.

\section{International Decade for Natural} Disaster Reduction.

The idea of the International Decade for Natural Disaster Reduction was originated at the Eighth World Conference on Earthquake Engineering, and fostered by enthusiastic efforts of scientists and engineers in the field of earthquake engineering. This is an important undertaking for the Association.

Dr. Frank Press, President of U.S. National Academy of Sciences, made a proposal, in his keynote address at the Eighth World Conference on Earthquake Engineering (8WCEE) in san Francisco, to immediately start planning an "International Decade for Natural Hazard Reduction (IDNHR)". The Executive Committee and the General Assembly of National Delegates, at 8WCEE, endorsed the proposal under the leadership of the international earthquake engineering community, and recommended a prompt action for implementation. The Executive Committee asked Executive Vice President J.T. Petrovski to lead the IAEE. The complete presentation was printed in the IAEE section of International Journal of Earthquake Engineering and structural Dynamics (JEESD).

The project has been seriously received in many countries. The idea has been endorsed at several international gatherings on natural disaster reduction, and attracted the attentions of a number of international organizations, such as the International Lithosphere Program, the International Association of Seismology and Physics of the Earth's Interior (IASPEI), the EuroInternational Committee on concrete (CEB), the International Council for Building
Research Studies and Documentation (CIB), the International Association for Bridge and structural Engineering (IABSE), the International Association for shell and Spatial structures (IASS), the International Union of Laboratories for Testing and Research for Materials and Structures (RILEM), the Wind Engineering Research Council, the Council on Tall Buildings and Urban Habitat.

The forty-second United Nations (UN) session adopted a resolution in support of the IDNHR program in December, 1987. The proposed resolution, initially cosponsored by Morocco and Japan, gathered 93 co-sponsors which exceeded 80 votes required to pass a resolution by a simple majority. The resolution designated the $1990 \mathrm{~s}$ as a decade in which the international community, under the auspices of the United Nations, would pay special attention to fostering international cooperation in the field of natural disaster reduction. The decade is now called "International Decade for Natural Disaster Reduction (IDNDR)".

The IAEE should formulate how to cooperate with the U.N. system to bring the IDNDR program to fruition in the next few years. The IAEE Secretary General and the Executive Vice-President were assigned to contact United Nations.

\section{International strong Motion Array Council (ISMAC).}

The IAEE Executive Committee approved the formation of the International strong Motion Array Council ISMAC) in 1981 under the chairmanship of Professor W.D. Iwan. The council held three meetings: 1) San Francisco in 1984 during the 8WCEE, 2) Tokyo in 1985 in conjunction with the 23 rd General Assembly of the International Association of Seismology and Physics of the Earth's Interior (IASPEI) and 3) Vancouver in 1987 on the occasion of the XIX General Assembly of the International Union of Geodesy and Geophysics (IUGG) .

Some of specific tasks have been assigned to sub-committees. Network and Array Design Committee, chaired by Professor J. Prince, was formed in 1984,1$)$ to survey design principles, and 2) to recommend installation and configuration guidelines for strong-motion arrays and networks. Mobile Arrays Committee, chaired by Professor M. Erdik, was formed in 1984 to 
discuss ISMAC's option and role for involvement in internatonal mobile arrays. sub-committee on Minimum Instrumentation arrays was formed in 1987,1 ) to survey the specifications for digital strong-motion instruments, and 2) to recommend minimum instrument specifications for different array applications. Joint with IASPEI, a working group on the Effect of Surface Geology on Seismic Motion was formed to develop a plan for an international experimental program and to test methods of estimating the effects of surface geology on seismic motion. The first joint meeting was held in Vancouver in 1987.

The council co-sponsored an international workshop on strong-Motion Data Processing with IASPEI in Vancouver in 1987 , 1) to exchange information on current practice in data processing, and 2) to agree upon standard testing procedures for instrumentation and processing.

The travel expenses of the committee members were partially supported by UNESCO. The assistance is much appreciated.

\section{Guideline for Earthquake Resistant Non- engineered Construction.}

The monograph committee for non-engineered construction, chaired by Dr. A.S. Arya, started the work of revising the Monograph in 1984. The committee met in Mexico City in 1985 to discuss the revised manuscript "Basic Concepts on Seismic Codes: Part 2 on Non-engineered Construction". The travel grants from UNESCO made the committee meeting in Mexico City possible. The UNESCO assistance is deeply appreciated.

The monograph, entitled "The Guideline for Earthquake Resistant Non-engineered Construction," was printed in July, 1987, with a financial aid from the Kajima Foundation.

\section{Ninth World Conference on Earthquake Engineering.}

The following tasks related to the organization of the World conference have been traditionally been the responsibility of the IAEE President: 1) to receive and acknowledge abstracts, 2) to appoint reviewers, and 3) to transmit the reviewed and ranked abstracts to the organizing committee for final decision.

The President received approximately 1,497 abstracts from 45 countries. Upon the request of the President in May, 1987, a total of 74 scientists and engineers from 14 countries agreed to review the abstracts. Three reviewers were appointed for each abstract. The review committee carefully examined the reviewers' rating, and the decisions were notified to the contact person of each abstract in early January, 1988 .

There have been many requests to the President's Office for the support of travel funds to attend the 9WCEE. I felt very sorry for not being able to help these people. It may be time to seek some means to meet these requests.

\section{Earthquake Hazards.}

Since the $8 \mathrm{WCEE}$, there have been reports of disastrous earthquakes.

A Chilean Earthquake occurred on March 3, 1985. Professor R. Flores Alvarez, National Delegate of Chile, reported that although modern construction behaved quite well, in general, the losses reached nearly 2 million dollars, affecting public works, hospitals, schools and 200,000 dwellings.

A magnitude 8.1 occurred on september 19, 1985, in the west coast of Mexico, followed by a magnitude 7.5 earthquake on september 20,1985 . Two successive earthquakes caused tragetic damages to human lives and properties in Mexico City, located more than $350 \mathrm{~km}$ from the epicenter.

On September 13, 1986, an earthquake of magnitude 6.2 occurred approximately $20 \mathrm{~km}$ from the city of Kalamata, Greece, and killed 20 persons and injured 500 persons. one five-story reinforced concrete and another five-story apartment buildings collapsed.

An earthquake of magnitude 5.4 hit El Salvador on October 10, 1986. The epicenter was only $2.2 \mathrm{~km}$ south of downtown $\mathrm{San}$ Salvador. Approximately 10 mid-rise engineered buildings were either severely damaged or collapsed. Large amplitude accelerations were recorded. About 1,400 people were estimated to be killed and 7,000 injured.

An earthquake of magnitude 6.8 occurred on November 15, 1986, in the sea $40 \mathrm{~km}$ to the east of Taiwan. Fifteen persons were killed and 41 were injured. Thirty-six buildings collapsed including three mid-rise buildings.

An earthquake of magnitude 5.9 occurred on October 1, 1987, approximately $20 \mathrm{~km}$ to the west of Los Angeles. The earthquake killed six persons, and caused loss of approximately 2.3 billion dollars.

We want to send our deepest sympathy to those suffered from the earthquakes.

\section{The Central office.}

The Central office of the IAEE was supported by Japan Association for Earthquake Disaster Prevention. Dr. Yutaka Osawa has served as Secretary General after the Sixth Gorld conference on Earthquake Engineering in New Delhi in 1977. The Office was assised by professors $T$. Katayama, T. Minami, and $\mathrm{S}$. Otani of the University of Tokyo in addition to Ms. M. Ohta of Association for Building Research Promotion for secretarial services.

The Central office has revised and published "Earthquake Resistant Regulations - A World List," which contains the earthquake design load requirements of each countries. The publication may be useful for intended revision of an earthquake 
resistant design code.

"International Directory of Earthquake Engineering" will be published soon after the 9WCEE, which will contain the national organization for earthquake engineering, and a list of research institutions with their principal contact persons. It is no more possible to list individual names of researchers in the volume.

It is unfortunate for the Association that Dr. Osawa expressed his desire to retire from the office of Secretary General due to the reason of poor health. On behalf of the Association, I want to congratulate on his excellent services and devotion to the Association. We all owe him an immense debt of gratitude.

\section{Concluding Remarks.}

At this time, I want to state my personal views. I have observed the preparation of the Ninth World Conference as the President of the Association and chairman of the Funds sub-committee under the 9WCEE organizing Committee. It requires overwhelming efforts to organize this size of the conference. We have reached a stage to review the type of the conference in order to continue the conference.

Toward IDNDR, the association should make active efforts to reduce the earthquake disaster. The association should coordinate different activities of the world in the area of earthquake disaster mitigation. We should propose a fundamental concept for anti-earthquake measures and plans, that may be adopted in various countries and regions.

Finally, I want to express my thanks to all of you. I have been delighted by the assistance I received during my service as the IAEE President.

Hajime Umemura

\section{REPORT OF THE IAEE SECRETARY GENERAL IN 9WCEE}

\section{General}

The last Conference was held in San Francisco during July 21-28, 1984. The Conference was sponsored by U.S. Earthquake Engineering Research Institute. The Steering Committee was headed by Professor Joseph Penzien. More than 1,500 persons registered from 60 countries. The proceedings were published in seven volumes and distributed during the conference.

The General Assembly of National Delegates and the Executive Committee Meetings were also held in this period at the same place. At the General Assembly of National Delegates, the following officers and Directors were elected:

President H. Umemura (Japan)

Executive Vice-president J. Petrovski

(Yugoslavia)

Vice-president K. Kubo (Japan)

\author{
Secretary \\ General \\ $\mathrm{Y}$ \\ I. N. Burgman (U.S.S.R.) \\ J. Carmona (Argentina) \\ B. Chandra (India) \\ M. Erdik (Turkey) \\ L. Esteva (Mexico) \\ G. Grandori (Italy) \\ A. Hizon (Philippines) \\ J. Kuroiwa (Peru) \\ A. Lopez-Arroyo (Spain) \\ T. Paulay (New Zealand) \\ J. Penzien (U.S.A.)
}

Osawa

(Japan)

The Central office was approved to locate in Tokyo. Japan . was selected as the host country for the 9WCEE at the General Assembly of National delegates. Professor Rodrigo Flores, Professor D.E. Hudson and Professor S.V. Poliakov were recommended by the Executive Committee for Honorary Members.

The IAEE Executive Committee and the Assembly of National Delegates endorsed the idea of an "International Decade for Natural Hazard Reduction" and recommended prompt action for implementation.

During the period of 1984 to 1988, the Association functioned through correspondence and an informal Executive Committee meeting.

\section{Membership of IAEE}

The application for membership was received by the Central office from three national organizations: Dr. Mohamed Sobaih, President of Egyptian Society for Earthquake Engineering submitted an application on April 29, 1985. Dr. Huixian Liu, President of Chinese Association of Earthquake Engineering, submitted an application on september 12, 1985. Dr. Adrian S. Scarlet, Chairman of Israeli Association for Earthquake Engineering (ISAEE) submitted an application on October 28,1985 .

The Executive committee voted favorably to the applications. We want to welcome the new member countries. The number of IAEE member countries has grown to 37 . These countries are: Argentina, Australia, Austria, Bulgaria, Canada, Chile, China, Colombia, Egypt, El Salvador, Ethiopia, France, German Democratic Republic, Federal Republic of Germany, Ghana, Greece, India, Indonesia, Iran, Israel, Italy, Japan, Mexico, New Zealand, Nicaragua, Peru, Philippines, Portugal, Romania, Spain, Switzerland, Turkey, United Kingdom, Union of Soviet Socialist Republics, United states of America, Venezuela, and Yugoslavia.

A membership application was filed to the Central office by the Icelandic National Society of Earthquake Engineering with the Statutes of the Society and list of current officers on June 27, 1988. This matter must be dealt with during the Executive committee meeting. 


\section{Change of National Delegates.}

The following changes of National Delegates were notified to the central office:

Austria: from Dr. R.L. Grossmayer to Dr. R.G. Flesch,

France: from Mr. J. Despeyroux to Mr. V. Davidovic,

German Democratic Republic: from Dr. P. Bormann to Dr. P. Knoll,

India: from Dr. S. P. Singh to Mr. V. Ramachandran,

Israel during the 9WCEE: Dr. Rosenthal,

Italy: from Dr. G. Grandori to Dr. G. Augusti,

Portugal: from Dr. J.F. Borges to Dr. A. Ravara,

U.S.A.: from Dr. M.S. Agbabian to Mr. F.E. McClure,

Venezuela: from Ing. A.E. Olivares to Ing. P. Lustgarten, and

Yugoslavia: from Dr. D. Jurukovski to Dr. P. Fajfar.

\section{Nomination Committee.}

The nominating committee, consisting of $\mathrm{Dr}$. $\mathrm{H}$. Umemura, Dr. D.E. Hudson and Jai Krishna, Submitted a slate of nominations for the offices of President, Executive Vice President, and eight Directors to the Secretary General. The nomination follows:

For President:

Dr. Giuseppe Grandori (Italy)

For Executive Vice-President: Dr. Anand S. Arya (India)

For Directors:

Prof. B. Chandra (India)

Prof. M. Erdik (Turkey)

Prof. L. Esteva (Mexico)

Dr. A. Lopez-Arroyo (Spain)

Dr. T. Kobori (Japan)

Prof. T. Paulay (New Zealand)

Prof. J. Penzien (U.S.A.)

Dr. N.N. Skladnev

\section{International Journal of Earthquake} Engineering and structural Dynamics

Upon request by the IAEE Executive Committee, the advisory Editorial Board of the International Journal of Earthquake Engineering and Structural Dynamics (EESD) agreed to expand "IAEE news" section and to reserve at least one page in each issue. The IAEE Central office was assigned to provide the news to the general editor.

At the Advisory Editorial Board meeting in Lisbon on the occasion of the Eighth European Conference on Earthquake Engineering, the journal was reported to publish 8 issues in 1987 to meet an increase in the amount of materials received by the publisher. It was suggested to place the length limit to future papers. Professor R.W. Clough expressed his desire to retire from the position of General Editor on the occasion of the Ninth World Conference on Earthquake Engineering, and Professor G.B. Warburton agreed to succeed the position for the period 1988-1991.

\section{Informal Executive Committee Meeting}

held in Tokyo on September 29, 1986, on the occasion of the International Seminar on Regional Development Planning for Disaster Prevention. Those present were President $H$. Umemura, Vice President $\mathrm{K}$. Kubo, Secretary General Y. Osawa, Directors L. Esteva, A.0. Hizon, J. Kuroiwa, Consultative Member 3. okamoto, and observers A.S. Arya, M. Hashizume, Y. Ishiyama, T. Katayama, T. Minami, K. Nakagawa, K. Toki, J.N. Vargas, and $R$. Yarar. The progresses in the preparation of the Ninth World Conference on Earthquake Engineering, the International Decade of Natural Hazard Reduction, and the work by Monograph Committee were reported.

\section{Earthquake Resistant Regulations - A World List}

"Earthquake Resistant Regulations - A World List" has been revised again, on the occasion of the 9WCEE. The Central office requested National Delegates to furnish information on the status of the regulations in the member countries. It is unfortunate that no response was received from many member countries. Sixteen countries revised the earthquake resistant regulation. Some are unavailable in English.

\section{Directory for Earthquake Engineering Research}

Directory of Earthquake Engineering Research will be revised after the Ninth World Conference of Earthquake Engineering. The directory contains, for each member country, the national organization and officers, a list of institutions working of earthquake engineering research with its principal contact member.

\section{Financial Report}

The expenses to operate the central office in Tokyo since April 1984 were as follows:

April 1984 to March $1985 ¥ 1,847,236$

April 1985 to March $1986 \quad ¥ 1,447,465$

April 1986 to March $1987 \quad ¥ 1,363,120$

April 1987 to March $1988 ¥ 1,367,438$.

The Japan Association for Earthquake

Disaster Prevention has generously provided the funds.

\section{Concluding Remarks}

Finally, let me add my personal thanks to the Association, to which I have served since the Sixth World Conference on Earthquake Engineering succeeding late Dr. John Kazuo Minami. I feel sorry but I have decided to retire from the office of the IAEE Secretary General due to my personal reason. There have been much more activities in which I wanted to be of service to the Association. I sincerely wish all of you present in this hall to continue your work, which, I believe, will serve the welfare of the mankind.

Thank you. 
ORGANIZATION OF INTERNATIONAI DECADE FOR NATURAL DISASTER REDUCTION AND POSSIBLE ACTIVTTIES OF IAEE

\section{Report of the IAEE Executive Vice-President} in 9 WCEE

The concept of a cooperative international program to reduce impact of natural hazards and creation of IDNDR, has first presented by Dr Frank Press, President of U.S. National Academy of Sciences in his keynote address at the Eighth World Conference on Earthquake Engineering in July 1984 in San Francisco. After the Conference, international interest began to build not only with respect to reducing the toll of earthquakes, but also with respect to other natural hazards. Interest in establishing an IDNDR continued to grow and U. S. National Academy of Sciences appointed Advisory Committee on IDNDR under chairmanship of Professor George W. Housner. The Advisory Committee with contribution of Japan, Mexico and Canada prepared an impressive monograph introducing the concept of IDNDR and pointing to opportunities for reducing global risk from natural hazards through the application of science and technology.

With enthusiasm of Dr Frank Press, President of U. S. National Academy of Sciences, being for the last four years eminent proponent of the idea of creation IDNDR, and under initial co-sponsorship of Japan and Morocco, a resolution was adopted by the Forty-second session of United Nations General Assembly to designate the 1990 's as a decade in which the international community, under the auspices of the United Nations, will pay special attention to fostering international cooperation in the field of natural disaster reduction.

On the request of United Nations Secretary General, International Ad Hoc Group of Experts for IDNDR, composed of 24 highlevel scientific experts in the relevant disciplines and government experts in disaster relief operations, has been established to assist Secretary General in planning of the activities and modes of organization of IDNDR. An International Group of Experts assisted by steering Committee of United Nations Agencies, held first its meeting in Geneva on 5-8 July, 1988, considering ten basic questions of organization of the activities. Three additional meetings will be organized in 1988 and 1989 in United States, Morocco and Japan in order to finalize the activities and their organizational modes to be implemented within IDNDR.

Extending hazard mitigation success to a global level is the obvious objectives of the IDNDR. With extensive participation of United Nations system, the key effort in organising the activities of IDNDR should be set by coordinated national, bi-lateral, regiomal and international activities, hoping that each interested nation wili declare its own plan of action. With establishment of national committees on IDNDR and efficient regional coordination, rational synthesis of existing knowledge and its practical implementation in mitigation of the risks from natural hazards could be achieved through development of pilot projects on major hazards in each region and thematic pilot projects to transfer scientific and technological achievements and to cover identified gaps. The role of the IAEE in creating, organizing and implementing the results of these pilot projects for earthquake disaster mitigation on national, regional and international level is of basic importance.

Earthquake Risk Reduction is based on a sequence of studies and actions which can be summarized in the following: earthquake monitoring; earthquake hazard assessment; vulnerability and earthquake risk assessment; earthquake risk reduction through undertaking engineering measures, land use planning, economic and general development planning, legislation, control insurance, public information, education and emergency measures.

In the Developed Earthquake Prone Countries earthquake hazard is identified with establishment of reliable earthquake monitoring system, appropriate data banks on intensity and frequency of occurrence of the earthquakes, and probabilistic presentation of earthquake hazard in a form of seismic zoning and microzoning for different return periods. Legislative measures and technical regulations are well established based on consistent experimental, theoretical and empirical studies. Engineering measures are consistently implemented for more than 30 years for buildings and structures, transportation and communication systems, lifelines, equipments, etc. Only recently, more consistent methods and techniques are developed for assessment of vulnerability and seismic risk, and rather limited quantifications are made for different elements at risk and their incorporation in land use and development planning process.

Development Earthquake Prone Countries are implementing with limited success developed technologies for earthquake risk reduction mainly due to lack of expertise, limited resources, and discontinuity of the original actions.

Considering an integral implementation of developed technologies for earthquake risk reduction and the need for their further improvement future efforts within IDNDR should be concentrated in the following areas: improvement of earthquake monitoring systems amd establishments of reliable data banks and information systems on regional level; establishment of uniform methods and procedure for earthquake damage assessment and its presentation; synthesis of existing knowledge, methods and procedures for implementation of engineering resources, quality-control and legislative measures; establishment of inventory of dominant elements at risk on international and regional level development and better quantification of relevant parameters for assessment of vulnerability and earthquake risk and their presentation to be directly implemented in the planning and decision 
making process; organization of intensive training of specialists in all fields; development of efficient systems for earthquake preparedness; creation of national systems for public information and continuous education.

Further quantification, verification and practical implementation of the scientiic and technological achievements for earthquake risk reduction could be received with organization and development of regional and thematic pilot projects in which IAEE in close cooperation with IASPEI and national committees should concentrate their future efforts.

\section{J. Petrovski}

\section{IAEE RESOLUTION}

1. The IAEE Execuctive Committee and the Assembly of the National Delegates wish to express their great appreciation of the Host organizations, the Science council of Japan, the Japan Association for Earthquake Disaster Prevention, and the five academic societies listed below, for the invitation to have the Ninth World Conference on Earthquake Engineering in Tokyo and Kyoto and to the 9WCEE steering Committee for the excellent planning and execution of this highly successful and fruitful event:

Architectural Institute of Japan,

Japan Society of Civil Engineers,

The Japan Society of Mechanical Engineers,

Japan Society of Soil Mechanics and Foundation Engineering, and

Seismological Society of Japan.

2. The Executive Committee and the Assembly of National Delegates would like to express their deep appreciation to Dr. Yutaka osawa, our retiring Secretary General, for his selfless dedication to the promotion of the activities of the IAEE. Without his efforts, smooth management of the Association would never have been possible.

3. By recognizing the profound importance of the International Decade for Natural Disaster Reduction (IDNDR), which was adopted as an official UN program at the Forty-Second General Assembly of the United Nations held in December 1987, the Executive Committee and the Assembly of National Delegates express their strong involvement in promoting, organizing and participating in the activities of the IDNDR.

4. The Executive Committee and the Assembly of National Delegates expresses their deep appreciations to Professor Emeritus Hajime Umemura, our retiring President, for his selfless dedication to providing outstanding leadership to the IAEE.

\section{ESTABLISHMENT OF JOINT COMMITTEE ON} GEOTECHNICAL HAZARDS FOR IDNDR

Following the resolution of the General Assembly of National Delegates of IAEE at the 9WCEE, and considering the important role of the international non-governmental organizations in promoting, organizing and performing the activities within framework of the International Decade for Natural Disaster Reduction (IDNDR), it is recommended to establish a JOINT COMMITTEE ON GEOTECHNICAL HAZARDS FOR IDNDR tentatively composed of IAEE and IASPEI, and to invite the International society for Soil Mechanics and Foundation Engineering (ISSMFE) and the International Association of Volcanology (IAVCEI, Working Group in the Mitigation of Volcanic Disasters) to participate in the activities of the Joint committee for IDNDR.

The Joint committee for IDNDR could consist of seven members: three nominated by the IAEE, two nominated by the IASPEI, and one each nominated by the ISSMFE and the IAVCEI.

The IAEE Committee on IDNDR as a part of the JOINT COMMITTEE ON GEOTECHNICAL HAZARDS FOR IDNDR is proposed to be composed of the following members:

Professor George W. Housner, Chairman Professor Jakim Petrovski, Member Professor Kenzo Toki, Member

Members of the Joint committee from IASPEI and their invited international associations (ISSMFE and IAVCEI) will be nominated by their respective associations. 